\title{
ERRATUM
}

\section{Preface: Nutrient sensing and signalling in the gastrointestinal tract - ERRATUM}

\author{
Soraya P. Shirazi-Beechey and David Bravo
}

(First published online 21 July 2014)

doi:10.1017/S000711451300233X, Published by Cambridge University Press, June 2014.

The reference list supplied at the end of the editorial in BJN $111 \mathrm{~S}^{(1)}$ is incorrect. The publishers apologise for this error. The correct reference list is supplied below $^{(1)}$.

References

1. Bayliss WM \& Starling EH (1902) The mechanism of pancreatic secretion. J Physiol 28, 325-353.

2. Sternini C, Anselmi L \& Rozengurt E (2008) Enteroendocrine cells: a site of 'taste' in gastrointestinal chemosensing. Curr Opin Endocrinol Diabetes Obes 15, 73-78.

3. Rehfeld JF (2004) A centenary of gastrointestinal endocrinology. Horm Metab Res 36, 735-741

4. Wellendorph P, Johansen LD \& Bräuner-Osborne H (2010) The emerging role of promiscuous 7TM receptors as chemosensors for food intake. Vitam Horm 84, 151-184.

5. Scott KP, Gratz SW, Sheridan PO, et al. (2013) The influence of diet on gut microbiota. Pharmacol Res 69, 52-60.

6. Daly K, Darby AC, Hall N, et al. (2014) Dietary supplementation with lactose or artificial sweetener enhances swine gut Lactobacillus population abundance. Br J Nutr 111, S30-S35.

\section{Reference}

1. Shirazi-Beechey SP \& Bravo D (2014) Nutrient sensing and signalling in the gastrointestinal tract. Br J Nutr 111, S1-S2, published by Cambridge University Press, doi:10.1017/S000711451300233X. 